\title{
A Survey on beggars with reference to Pune city
}

\author{
Dr. Ejaz Qureshi
}

Director at Rajarshi Shahu Institute of Management, Aurangabad, ejaz1963@ rediffmail.com

Prof. Md. Saad Siddiqui

Shreeyash College of Engineering \& Technology, Aurangabad, siddiqui.saad01@ gmail.com

\section{Dr. Preeti Sharma}

Director Trinity Institute of Management and Research, Pune, profpreetisharma@ gmail.com

\begin{abstract}
:
Begging, a social scourge, has become a relatively common profession in India. As for as Pune city is a concern there are several beggars. These beggars are at the age of minority to adult age. The majority of the beggars are physically disabled and this physical disability is the most common reason to beg.

Through the present study an attempt has been made to focus on the types of physical disability of beggars, reasons for getting into the begging profession, daily earing of beggars in Pune city and the relation between physical disabilities with respect to daily earning of baggers.
\end{abstract}

Keywords - Beggars, Physically Disability, Daily earning, Impairment

\section{Introduction:}

Pune city being metropolitan of India with approximately 82 lacks population is also known as automobile and IT hub. It also has research institutes for IT, education that attracts migrants, students and professionals from all over India. Pune is also the very fastest-growing city in Asia-Pacific. It also stands 8th rank in metro ranking. Living of standard in Pune is very high and the city hosts fairly rich communities.

Beggars have increased in every city of India and Pune is not an exemption for this. Just like lawyers, engineers, athletes and administrators, beggars can be very professional. Even if beggars do not have any union or association, they unite to define their source of income. There are several varieties of beggars; some are blind, while others are abandoned by their families.

There are various reasons for begging and the most common reason is physically handicapping. It is the only means for their survival. In India where many linguistic and 
cultures are in existence, people are more keen and emotional towards their religion, so it becomes very easy to earn money in the name of religion and in the name of a different god. It is simple to make a lot of money. Every place has at least one worship place of different religions and many beggars can be identified in front of these places, this is the most common and perfect place to beg. This is just one side of the story; poverty is the real problem in India but not begging. Due to poverty beggars are increasing day by day. In India begging becomes a serious problem for many decades. For many beggars, begging is like just any other profession. They go out of the home to earn money not by working but by begging. In metros and cosmopolitan there are gangs and groups of beggars directed by a leader. Each leader sends the group of the beggar to a particular decided spot of the city to beg.

Today, identifying the genuine and hungry beggar has become quite tough. Sometimes beggars have become very determined in begging that we are bound to give them money only. In Pune, the number of people begging has increased dramatically. Government, NGOs and other social organizations claim that many measures have been taken to eliminate or to break to begging in the city but the trend of begging is still going on. People are very traditional and god-fearing having a religious frame of mind, these costs to go throw money into the pot of beggars and hence the number of beggars is increasing in the city.

Many government bodies, NGOs are working to reduce beggars. Nuisance detection Squad has an annual allocation of Rs. 42 lakhs speciality provided to deal with begging problems of the city. As far as child beggar and women beggar is concern they arrest such beggar and put them into women and Child Development Committees of the corporation for the rehabilitation programme to look into it. Some beggar earns a handsome amount of money every day and every year. Pune has an apartment and town system, therefore beggars can be found near religious sites, traffic signals, bus stops, roadways, railway stations, and marketplaces. The current trend among the beggars is that their preference to get cash money from the people rather than asking for food or food grains. They try to get cash from people hence their income is quite high. Physically challenged beggars to get more money than a capable beggar. Handicapped beggars easily catch the attention of people and get cash from them.

\section{Objectives:}

- To learn about the beggars' economic situation and how they make a living.

- To determine the relation of physical disability with respect to their income.

- To study the different reasons for getting into the begging profession.

\section{Research Methodology:}

A pilot study was carried out in different crowded areas of Pune city. We planned to target the beggar profession, in particular, to find out their livelihood and at par their economic condition. The number of beggars is growing every day. Our survey consists of 200 
sample size but the real respondents are 150 , rests 50 were reluctant to give answer to our questions. Structured questions were designed in Hindi and English and questions were designed with 20 itemized questions covering up the entire survey in the areas to support our findings, such as beggar economic conditions, relationships between physical impairments and beggar income, lucrative places for beggars, motivations for begging, and the role of NGOs and the government in beggar rehabilitation.

\section{Literature Review:}

As per the study on Beggars in rural areas: A socio-economic analysis by Dr. Jabir Hasan Khan, Dr. Menka, Shamshad The rural beggars of the district are mainly involved in their ancestral activity i.e. begging for their survival having very low income and high dependency ratio. They have very little access to educational opportunities and other modern household amenities and assets. Nevertheless, radio and cycle are the only assets which were mainly found within their households used for entertainment and transportation for begging purposes respectively. Thus, the rural areas of the district may be developed other opportunities for work by promoting the agro, agro-allied and ancillary industries as animal husbandry, poultry, fisheries, horticulture, floriculture, dairy, piggery, apiculture, silviculture, sericulture etc.

According to Gillian in 1929, he studies that the Socio-Economic situation of the country results in beggary and vagrancy. He also searches the main grounds which give rise to begging. The factors were including economic, social disorganization, political instability, break down of agriculture, religious ideals practices, the crusades, migration decay of feudalism, a plague of famine.

Gore, et al research1959 investigates the nature of the difficulties of beggars in a metropolitan like Delhi and recommended ways for its solutions. The issue is linked to our socioeconomic structure, which cannot be resolved entirely at the local level.

In 1959, a pilot survey on typology by Murti in greater Bombay with a view to result out the causes of beggary, types of beggars, the degree of the beggar problem and the possible methods of rehabilitating the beggars.

Study in Mirat and Kanpur by Prasad and rattan in 1960,61 suggested problems of the beggars and their remedial measures.

As per the socio-psychological study of beggars in 1973 by Ramana and Rao has mentioned that industrialization and urbanization have always entailed a heavy social cost.

In 1979 study of Jha made an attempt to find out beggars social stratification, cultural identity and above all to know their problems empirically.

Chaudhari investigated the socioeconomic position of beggars in Kalighat, a prominent Hindu destination in Kolkata, in 1987. The study inquired about the background of beggars and the social-cultural and behaviour which they manage to survive in their miserable socio-economic situation. 
Jowett, et al. (2001) presented a report about begging in relation to drugs and alcohol and homelessness based on research carried out in Manchester, Bristol, London and Brighton, involving people who beg, the public, police officers, hostel and day centre staff. This report investigates what money from begging is spent on, the reasons why people beg and public perspectives on begging.

Lynch (2005) gave an overview of the problem of begging and the public interest and value in responding to that problem. He also discusses a range of legal and public policy initiatives, both domestic and international, designed to respond to begging.

Goyal (2005) also focuses on specific social, cultural and behavioural strategies by which the beggars managed to survive in their miserable socio-economic situation.

Carter (2007) provides valuable insights into who panhandles and why they are on the streets of North American cities.

Stef and Jef (2011) devised and tested a method for estimating beggars' earnings in Brussels.

\section{Data Analysis and Interpretation:}

$\underline{\text { Table No. } 1}$

Physical Ability and Disability of the respondents

\begin{tabular}{|c|l|c|c|}
\hline Sr. No. & \multicolumn{1}{|c|}{ Physical Disability } & Frequency & Percentage \\
\hline 01 & Yes & 91 & $61 \%$ \\
\hline 02 & No & 59 & $39 \%$ \\
\hline & Total & 150 & $100 \%$ \\
\hline
\end{tabular}

As per the collected primary information it is observed that the majority of the respondents (beggars) that is $61 \%$ are having a physical disability on the contrary $39 \%$ of respondents have not any type of physical disability. It indicates that physical disability pushed the respondents in the begging profession.

$\underline{\text { Table No. } 2}$

If yes, what is the type of physical disability?

\begin{tabular}{|c|l|c|c|}
\hline Sr. No. & \multicolumn{1}{|c|}{ Age Group } & Frequency & Percentage \\
\hline 01 & Lost limbs & 16 & $17 \%$ \\
\hline 02 & Lost both limbs & 0 & - \\
\hline 03 & Leprosy Affected & 7 & $8 \%$ \\
\hline 04 & Other & 33 & $36 \%$ \\
\hline 05 & Not applicable & 36 & $39 \%$ \\
\hline & Total & 91 & $100 \%$ \\
\hline
\end{tabular}


As per the information provided by the respondents, it is observed that $17 \%$ of them have lost their limb, $8 \%$ of respondents are badly affected by leprosy disease and $36 \%$ of the respondents having other types of physical disability like deafness, dumbness, blindness and loss of any organ of the body. Other factors, such as acute poverty, a lack of employment, and so on, have caused $39 \%$ of respondents to beg.

\section{Table No. 3}

Reasons for getting into the begging profession.

\begin{tabular}{|c|l|c|c|}
\hline Sr. No. & \multicolumn{1}{|c|}{ Reason } & Frequency & Percentage \\
\hline 01 & Forced begging & 33 & $22 \%$ \\
\hline 02 & Urban mobilization & 00 & - \\
\hline 03 & Easy Income & 00 & - \\
\hline 04 & Physical disability & 91 & $61 \%$ \\
\hline 05 & Being neglected by family members & 26 & $17 \%$ \\
\hline & Total & 150 & $100 \%$ \\
\hline
\end{tabular}

There are several reasons for getting into the begging profession. As per the collected information, it is observed that $22 \%$ of the respondents are forcefully pushed into the begging profession. Especially children in the age group of 6 years to 12 years are dragged, beaten forced to beg every day. Apart from this, sometimes social disorders like cultural conflicts community disorganization etc. caused begging. It is also observed that the majority of the respondents $61 \%$ are physically handicapped or mentally retarded, diseased or suffering from chronic illness etc. for which they have accepted begging as their profession for their daily bread. $17 \%$ of the respondents have accepted begging as their profession because of total negligence by their family members due to the breakdown of joint family, family conflicts etc. majority of the respondents are children in this category.

\section{$\underline{\text { Table No. } 4}$}

\section{Daily earning through begging}

\begin{tabular}{|c|l|c|c|}
\hline Sr. No. & \multicolumn{1}{|c|}{ Particulars } & Frequency & Percentage \\
\hline 01 & Less than Rs. 100 & $\mathbf{4 3}$ & $29 \%$ \\
\hline 02 & Rs. 100-300 & $\mathbf{1 0 7}$ & $71 \%$ \\
\hline 03 & Rs. 300-500 & $\mathbf{0 0}$ & - \\
\hline & Total & $\mathbf{1 5 0}$ & $100 \%$ \\
\hline
\end{tabular}

As per the information provided by the respondents, it is found that $71 \%$ of the respondents are earning Rs. 100 to Rs. 300 daily through begging and $29 \%$ of the respondents daily earning through begging is less than 100 Ts. Daily. There is no respondent found who earn Rs. 301 to Rs. 500 daily through begging. 
$\underline{\text { Table No. } 5}$

Earning on a special day

\begin{tabular}{|l|l|l|l|}
\hline Sr. No. & \multicolumn{1}{|c|}{ Particulars } & Frequency & Percentage \\
\hline 1 & No & 42 & $28 \%$ \\
\hline 2 & Yes & 108 & $72 \%$ \\
\hline & Total & 150 & $100 \%$ \\
\hline
\end{tabular}

$28 \%$ of respondents have stated that they do not earn any extra money on a special day like festivals, fairs etc; whereas $72 \%$ of the respondents have stated that, they earn extra money on the religious festivals, fairs, national days, and so on.

\section{$\underline{\text { Table No. } 6}$}

Venue of staying

\begin{tabular}{|c|l|c|c|}
\hline Sr. No. & \multicolumn{1}{|c|}{ Particulars } & Frequency & Percentage \\
\hline 01 & In slum area & 100 & $67 \%$ \\
\hline 02 & At Footpath & 31 & $20 \%$ \\
\hline 03 & Underbridge & 09 & $6 \%$ \\
\hline 04 & Other & 10 & $7 \%$ \\
\hline & Total & 150 & $100 \%$ \\
\hline
\end{tabular}

In India, one can see beggars in almost all the public places, nearby temples mosques markets, railway stations etc. As per the collected information, it is found that $67 \%$ of the respondents are staying in slum areas in Pune city. $20 \%$ of respondents are homeless and staying on the footpath for a shelter. $6 \%$ of the respondents have taken shelter under bridges, and $7 \%$ of the respondents staying under the tree on the campus of temples, mosques and at any other religious place etc.

Table No. 7

Relationship between physical impairment and daily earnings

\begin{tabular}{|c|l|c|r|c|c|}
\hline Sr. No & Physical Disability & Frequency & Daily earning & Frequency & Percentage \\
\hline \multirow{2}{*}{01} & \multirow{2}{*}{ Yes } & \multirow{2}{*}{91} & Less than Rs. 100 & 24 & $16 \%$ \\
\cline { 4 - 6 } & & Rs. 100-300 & 67 & $45 \%$ \\
\hline \multirow{2}{*}{02} & No & \multirow{2}{*}{59} & Less than 100 Rs. & 19 & $12 \%$ \\
\cline { 4 - 6 } & & & Rs. 100 to 300 Rs. & 40 & $27 \%$ \\
\hline & Total & 150 & & 150 & $100 \%$ \\
\hline
\end{tabular}


The above table indicates the relation between the physical disability of beggars and their daily earnings. According to the data gathered, 16 percent of disabled respondents earned less than 100 rupees. Daily whereas $45 \%$, disabled respondents earn between Rs. 100 to 300 Rs. daily. On the contrary, it is found that $12 \%$ of abled respondents earned less than Rs. 100 daily through begging and 27\% respondents earned between Rs. 100 to 300 Rs. daily through begging. The collected primary information indicates that, the number of physically disabled respondents who earned Rs. 100 to 300 Rs. daily are more than the number of physically abled respondents. It also clearly shows that physically disabled and mentally retarded are the major causes of social evil like begging in India.

\section{Findings:}

According to the study, 91 respondents are physically disabled due to this reason/helplessness they are into the begging profession. 59 people are physically fit.

As per the study, 33 respondents have the Forced Begging of being into this profession whereas 26 beggars are neglected from their homes and family members.

107 beggars out of 150 earn between Rs. 100 to Rs. 300 every day, whereas 43 beggars earn less than Rs. 100 per day.

As per the feedback given by 108 beggars, they earn special or more income than the regular days and those days are Thursday and Friday. 42 beggars don't earn more income apart from their regular income on any day.

The survey shows that 119 beggars have their home to stay, where 31 beggars don't have a home and stay at a footpath.

This survey clearly shows that there is a relation between physical inability and income. 67 physically disabled beggars earn between 100 to 300 and 40 physically abled beggars earns less than Rs. 100- Rs. 300.

\section{Suggestions}

1) All the local level beggars should be registered properly and given IDs and proper reasons for their being beggars should be asked.

2) Those who are physically able but do not have any resources or employment should be given employment opportunities through NGOs or make available resources to them to become self-suffice.

3) There should be more rehabilitation centres, open to accommodating old age, physically disabled and forced beggary etc.

4) Old age and physically disabled who are capable of doing certain jobs should also be given training in sewing weaving, binding etc.

5) The campaign should be carried on the encourage people not to give money directly to beggars but to donate to the fund created by the government. 


\section{Reference:}

- Carter, T. (2007). Panhandling in Winnipeg: legislation vs support services. University of Winnipeg.

- Chaudhuri, S. (1987). Beggars of Kalighat, Calcutta. Calcutta: Anthropological Survey of India, (MHRD).

- Das, D. K. L. (1983-84, July-April). Evaluation of beggar problem in Tirupati. Social Defence, 19.

- Dr. Jabir Hasan Khan, Dr. Menka, Nisar Ahmed (2013). Availability Of Household Facilities Among Beggars' Households: A Regional Analysis Ournal Of Arts, Science \& Commerce, Vol.-Iv, Issue-3,

- Dr. Jabir Hasan Khan, Dr. Menka, Shamshad (2009). Beggars in rural areas: A socio-economic analysis, IOSR Journal Of Humanities And Social Science (IOSRJHSS) Volume 14, Issue 6 (Sep.-Oct. 2013), PP 122-12

- Dr. Menka,Prof. Jabir Hasan Khan ,Shamshad (2014). Socio-Economic Status of Beggars in Urban Areas: A Case Study, vol. 3, no. 9,

- Fitzpatrick, S. \& Kennedy, C. (2001). Getting by begging, rough sleeping and the issue in Glasgow and Edinburgh. Bristol: The Policy Press.

- Gillin, J. L. (1929, November). Vagrancy and begging. American Journal of Sociology, 35(3).

- Gore, M. S., Mathur, J. S., Laljani, M. R. \& Takulia, H. S. (1959). The beggar problem in metropolitan Delhi. Delhi: School of Social Work.

- Goyal, O. P. (2005). Anti-social pattern of begging and beggars. Gyan Publishing House.

- Jha, M. (1979). The beggars of a pilgrim's city: anthropological, sociological, historical \& religious aspects of beggars and lepers of Puri. Varanasi: Kishor Vidya Niketan, Bhadaini.

- Jowett, S., Banks, G. \& Brown, A. (2001). Looking for change: the role and impact of begging on the lives of people who beg. Communities and Local Government.

- Lynch, P. (2005). Understanding and responding to begging (Australia). Melbourne: University Law Review.

- Moorthy, M. V. (1959). Beggar problem in greater Bombay: a research study. Bombay: Indian Conference of Social Work.

- Prasad, L. (1960). Beggar Problem in an Indian Provincial Town. The Indian Journal of Social Work,21(2), 147-153.

- Ramana, K. V. \& Rao, P. K. (1973, January). No Option but Beggary. Social Welfare, 19 (10), 13-14.

- Rao, T. S., \& Bogaert, M. V. D. (1970). The Beggar Problem in Ranchi. The Indian Journal of Social Work, 31(3), 285-302.

- Ratan, K. (1961). Beggar Problem in Kanpur. The Indian Journal of Social Work, 21(4), 397-401.

- Stef, A. \& Jef, H. (2011, January). Street-Level Informal Economic Activities: Estimating the Yield of Begging in Brussels. Urban Studies, 48, 23-40. 